\title{
Crowding-In : How Indian Civil Society Organizations Began Mobilizing around Climate Change
}

\section{Ylä-Anttila, Matti Tuomas}

2017

Ylä-Anttila , M T \& Swarnakar, P 2017 , ' Crowding-In : How Indian Civil Society Organizations Began Mobilizing around Climate Change ', British Journal of Sociology , vol. 68 , no. 2 , pp. 273-292 . https://doi.org/10.1111/1468-4446.12251

http://hdl.handle.net/10138/311266

https://doi.org/10.1111/1468-4446.12251

unspecified

acceptedVersion

Downloaded from Helda, University of Helsinki institutional repository.

This is an electronic reprint of the original article.

This reprint may differ from the original in pagination and typographic detail.

Please cite the original version. 


\section{Crowding-In: How Indian Civil Society Organizations Began}

\section{Mobilizing around Climate Change ${ }^{1}$}

Tuomas Ylä-Anttila and Pradip Swarnakar

April 2016, accepted for publication in British Journal of Sociology

\section{Abstract}

This paper argues that periodic waves of crowding-in to 'hot' issue fields in are a recurring feature of how globally networked civil society organizations operate, especially in countries of the Global South. We elaborate on this argument through a study of Indian civil society mobilization around climate change. Five key mechanisms contribute to crowding-in processes: (1) the expansion of discursive opportunities, (2) the event effects of global climate change conferences, (3) the network effects created by expanding global civil society networks, (4) the adoption and innovation of action repertoires and (5) global pressure effects creating new opportunities for civil society. Our findings contribute to the world society literature, with an account of the social mechanisms through which global institutions and political events affect national civil societies, and to the social movements literature by showing that developments in world society are essential contributors to national mobilization processes.

Keywords: civil society; climate change; India; world society; environmental social movements; social mechanisms 


\section{Introduction}

The world society literature has convincingly argued that the worldwide expansion of environmentalism during the last century has largely been driven by global cultural and institutional change. States, especially in the Global South, and civil society organizations (CSOs) have enacted cultural models of environmental protection embedded in a global environmental regime comprising interstate institutions and treaties, institutionalized environmental sciences and international CSOs (Haas 1992; Meyer et al. 1997a; Frank et al. 2000; Schofer and Hironaka 2005). The world society literature, however, has paid relatively little attention to the meso-level mechanisms through which the global influences the national and local. This paper uses insights from the social movements literature to examine these mechanisms.

We look at the interactions between global institutions of climate change governance and national CSOs through a case study on India. The institutionalization of climate change governance and related political processes have been one of the most important developments in global environmentalism since the 1990s. In India, the effects of these global processes are presumed to be particularly strong for several reasons. First, world society influences on countries in the Global South, especially in relation to civil society, have been stronger than on countries in the Global North (Frank et al. 2007; Longhofer and Schofer 2010). Second, the consequences of climate change to the ecosystem and human livelihoods in India are exceptionally strong, due to its geography and the 
high proportion of the population living off subsistence farming and fishing, adversely affected by the increasingly unpredictable climate. This is likely to put climate change strongly on the political agenda. Third, due to its large population and rapidly growing economy and emissions, India is one of the most important players in the international climate negotiations. This has resulted in considerable pressure from global institutions on India to act on climate change. Fourth, India has an exceptionally vibrant civil society, which makes it particularly well suited for developing our arguments about interactions between global institutions and national CSOs.

We make two main contributions to the world society literature. First, we argue that the increase in the influence of world culture and global institutions on national societies often occurs in waves characterized by processes of crowding-in of CSOs in 'hot' issue fields. Second, we use a process and mechanism approach developed in social movements studies to outline five meso-level mechanisms that drive these crowding-in processes: (1) the expansion of discursive opportunities, (2) the event effects of global conferences, (3) the network effects created by expanding global CSO networks, (4) the adoption and innovation of action repertoires and (5) global pressure effects that propel states to act in ways that unveil opportunities for CSOs. Moreover, we contribute to the social movements literature by showing the extent to which a national-level mobilization process such as the one on climate change in India can be driven by global institutions, and by detailing the mechanisms through which this influence occurs. 
The paper is organized as follows. The next section reviews arguments by world society scholars on the interaction between global institutions and national CSOs and outlines our approach, drawing on social movements literature, to investigating the mechanisms involved in this interaction. We then proceed to present our materials and methods, before moving on to define the concept of crowding-in and present evidence suggesting that such a process has occurred in the field of climate politics in India. The following five sections consecutively examine the role of five key mechanisms driving this process. Finally, we discuss the transferability of our conclusions and point out directions for future research.

\section{Analytical perspective: the mechanisms driving national crowding-in processes on global issues}

A global phenomenon, climate change has attracted intense scientific, institutional, political and discursive responses at the global level during the last two decades. The institutionalization of climate science and the Intergovernmental Panel on Climate Change (IPCC), the annual interstate negotiations within the framework of the United Nations Framework Convention on Climate Change (UNFCCC) and the resulting media attention have contributed to the rise of climate change high on the global political agenda. This paper looks at the connections between these global processes and the mobilization of CSOs at the national level.

The literature on world society and environmentalism has made important contributions to the understanding of connections between the global and the local. It argues that interstate institutions and international environmental CSOs 
have been important carriers of global environmentalism and that states and national environmental CSOs often follow global agenda-setting trends (Frank et al. 2000). Thus, almost all national environment ministries were established after the founding of the UN Environmental Programme (UNEP) at the UN Conference on the Human Environment in Stockholm in 1972, a landmark event in the global institutionalization of environmentalism (Frank et al. 2000; Hironaka 2014). Further, in the Global South, domestic environmental CSOs usually begin to proliferate only after international CSO chapters have been established in countries in question (Frank at al. 2007; Longhofer and Schofer 2010).

The world society literature has mostly utilized quantitative macro datasets that 'effectively measure larger and more mainstream environmental groups' (Longhofer and Schofer 2010: 507). We go beyond this literature to show that during intense crowding-in processes, many smaller, often newly founded organizations and those from adjacent issue fields enter an emerging field as it gathers momentum (such as development-related organizations entering the field of climate change). The activities of such organizations remain largely invisible to the CSO directories used to construct quantitative datasets. Nevertheless, crowding-in processes are, we argue, an important part of how globally networked CSOs operate, especially in the Global South.

Moreover, due to its macro focus, the world society literature has paid relatively little attention to the meso-level mechanisms through which global forces affect social change nationally and locally (see, however, Boyle 2002; Tsutsui 2006; Tsutsui and Shin 2008). We add to this literature by arguing that 
the influence of world society on national CSO mobilization often happens in waves of crowding-in and by specifying five mechanisms that drive such waves.

For this purpose, we use a mechanism and process-based approach from the field of social movements studies (McAdam et al. 2008, 2001). This approach understands political processes as consisting of causal mechanisms, that is, 'delimited changes that alter relations among specified sets of elements in identical or closely similar ways over a variety of situations' (McAdam et al. 2008: 308). Some proponents of this approach have argued that 'to describe the unfolding of the actual process is to explain it' (Bosi et al. 2014: 4). We add that to produce a more sociologically interesting explanation, the description of a process - or 'process tracing' - (George and Bennett 2005) ought to focus on those elements of the process that have already occurred and/or are likely to recur in other similar processes, that is, to focus on social mechanisms understood as 'partial causal analogies' (Tilly 2001: 24). This approach steers the analysis to the middle ground between purely idiosyncratic historical explanations and the standard approach to causality underpinning studies on statistical correlations between variables. It does, however, allow for a degree of generalization from well-chosen cases, which makes it suitable for the current study.

\section{Research materials and methods}

Our data sources include (1) a survey of 259 Indian organizations working on climate change (Mehra 2010), (2) a dataset on the Indian media's coverage of climate change ( $N=9,328)$ (Daly et al. 2015), (3) 21 semi-structured interviews, (4) an extensive collection of CSO websites, newsletters, reports and other 
printed material and (5) participant observation at climate change related events, such as meetings of the Indian Climate Research Network and the Delhi Sustainable Development Forum.

Our primary data source for identifying CSOs working on climate change and for supporting our argument that a crowding-in process occurs is a survey dataset on organizations from all sectors working on the issue of climate change in India (Mehra 2010). To investigate the mechanisms driving the crowding-in process, we draw on a more limited, though more in-depth, sample of twentyone semi-structured interviews, documents obtained online and from the organizations interviewed and participant observation. To select the interview sample, we began with the list of survey respondents, and added several other sources: the member lists of the main civil society networks on climate change CAN and CJN!, lists of CSOs accredited as observers in UNFCCC meetings, and a list of signatories to an open letter from CSOs to the Prime Minister of India on Climate Change (Dharmadhikary et al. 2009), and suggestions by earlier interviewees. This process led us to add 84 organizations to the list. The complete list and details of the selection process are available online at bit.ly/CSOlist.

To select the twenty-one organizations to be interviewed in depth from this list, we first ensured the inclusion of all the most influential organizations in climate change advocacy based on earlier literature (Dubash 2009; Lele 2012), documentary and online research, a wide sample of media coverage on climate change we had collected for another research project (Author B et al. 2012) and, later, assessments of other interviewees. Analyzing the first interviews and 
documents led us to begin developing the crowding-in hypothesis and focus the later interviews on this phenomenon. We were struck by the similarity of the first stories we heard. All organizations had either been started or had reoriented their activities towards climate change around the same time. All mentioned the role of international institutions and related events such as the 4th assessment report of the IPCCC in 2007 and the upcoming COP 15 conference in 2009 as something that had contributed to this decision. Most talked about the importance of international civil society networks in taking the decision and acting on it.

It is also important to note that this early development of the hypothesis guided our sampling for the remaining interviews. As we began to conceive crowding-in as something that entails the diversification of the range of organizations active in the field, we sampled to maximize diversity (cf. Weiss 1994: 22; Miller 2000: 77; Krause 2014: 179-181; Della Porta 2014: 241). That is, rather than striving for a sample that would be a miniature of the organizational field including the same proportions of each type of organization as the field does, we picked a youth organization and a cultural organization as we found those types of organizations, too, had begun to work on climate change. This sampling strategy is reflected in our argumentation and use of quotations from the interviews as evidence. Most quotes exemplify what the interviews show generally. Others, however, are sociologically interesting not because of their prevalence in the material, but because they reflect how far the crowding-in process extends (such as the quote from INT06 in the section on network effects below, showing the importance of interpersonal networks in getting a former 
youth cultural organizer involved in climate change advocacy). The interviews are referred to in the text by their codes (INT1, INT2 ...) as listed in Appendix 1

The interviews, between 45 minutes and two hours long, were recorded, transcribed and manually coded. The coding process involved the two authors reading through the material and proceeding from simple observations towards more general categories through discussions and additional reading of the research literature, resulting in an inter-subjective, theory-informed coding process (cf. McCracken 1998: 30-32; Weiss 1994: 151-156; Kvale 2008: 101-119; Della Porta 2014: 249-253).

\section{The crowding-in of CSOs in climate change advocacy}

Since the creation of the UNFCCC regime, two CSOs have been instrumental in shaping national climate policy and the position of the Indian government in global negotiations. The Center for Science and Environment (CSE) published an influential report 'Global Warming in an Unequal World' in 1991, the year preceding the founding of the UNFCCC at the Rio Earth Summit. The report argued for the historical responsibility of industrialized countries and their need to cut 'luxury emissions' (Agarwal and Narain 1991). This position was swiftly adopted by the Indian government at the UNFCCC and found support among a global coalition of CSOs, which helped to put the principle of common per capita emissions on the global negotiating agenda (Rahman and Roncerel 1994). TERI, likewise, has been influential in climate change politics not only in India but also at the global level: its head, Rajendra Pachauri, became the chairperson of the IPCC in 2002. CSE and TERI were ranked nineteenth and twenty-first, respectively, on the Global Go To Think Tank Index of the world's most 
influential environmental think tanks, with only two other institutions outside Europe and North America making the top 21 (McGann 2013).

Since around 2004, however, the number and diversity of CSOs working on climate change has increased dramatically, with the sharpest increase taking place in 2007. Before 2004, the number of new organizations entering the field each year was less than five, rising to ten in 2005 and twenty in 2007. Figure I shows this sharp increase.

Figure I. Cumulative count of Indian CSOs reporting activities related to climate change $(\mathrm{N}=91)^{*}$ and the number of articles per year on climate change $(\mathrm{N}=9,328)^{* *}$.

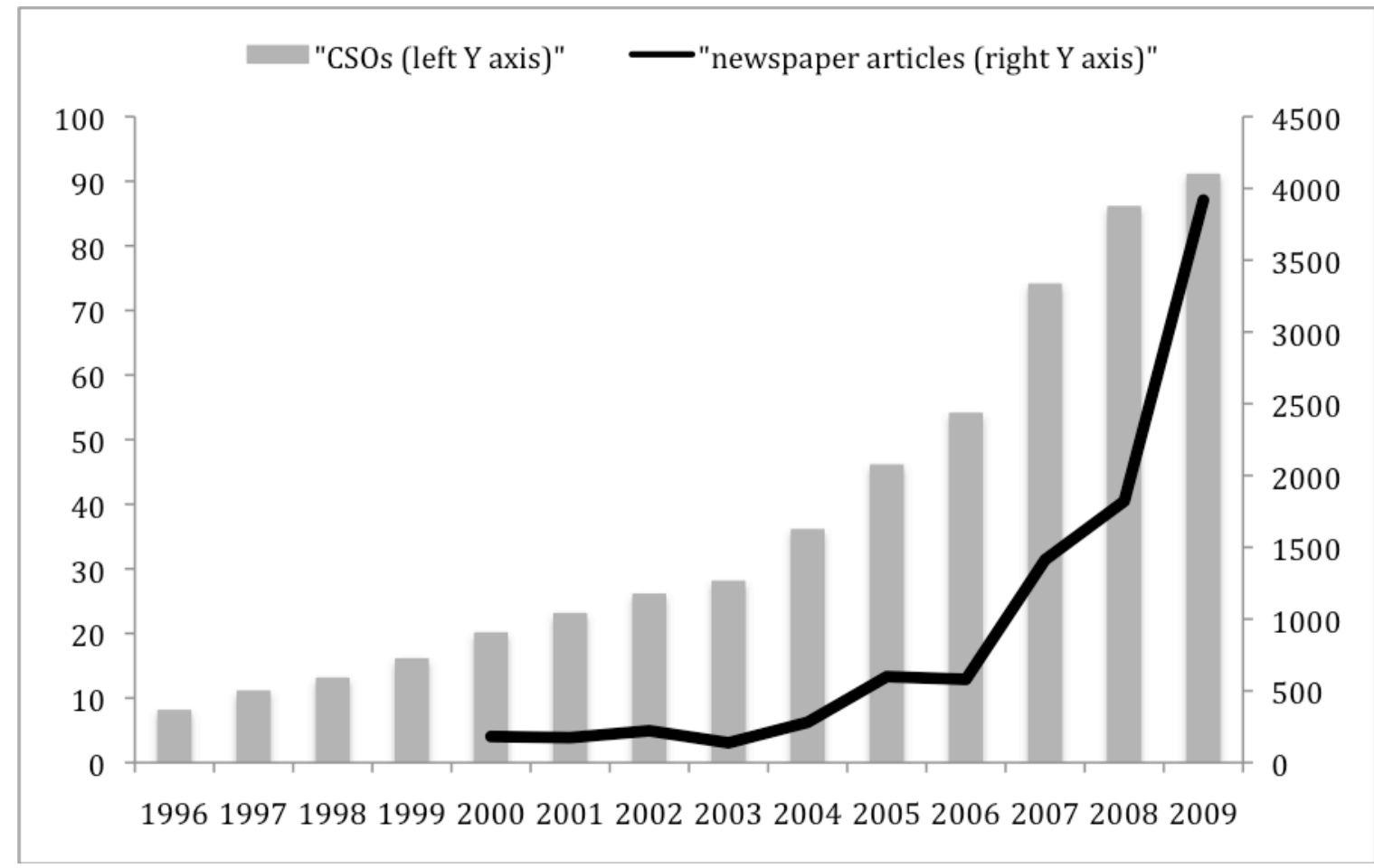

* Data source: Mehra (2010).

** Data source: Daly et al. (2015). The combined count for the four major newspapers in

English: The Hindu, The Times of India, Hindustan Times and The Indian Express. 
Besides the growth in numbers, the diversity of organizations involved has expanded. From the early starters, CSE and TERI, to the obvious environmental CSOs like WWF India, the field now includes organizations such as the Center for Social Markets, Carbon Minus India, the Indian Youth Climate Network and MigrantWatch, all reporting having commenced work on climate change in $2007 / 8$. These four organizations represent the various trajectories of organizational entry into the field. The Center for Social Markets was founded as a corporate social responsibility organization in 2002 , but in 2007 , it concluded: 'climate was having a huge impact, and we found that business has the power to actually influence climate change and the other way around' (INT17) ${ }^{1}$. Consequently, it now includes the words Climate. Sustainability. Market. (in this order, including the full stops) in its logo. Conversely, Carbon Minus India is a spin-off from the long-established Indian Institute for Sustainable Development, which in 2007 founded an independent organization that reports having 67 employees dedicated exclusively to climate change. The Indian Youth Climate Network was established in 2008 when four students in Delhi 'thought that there was no youth representation in the matter of climate change' (INT11) and managed to secure funding to travel to the Poznan COP and subsequently embark on a campaign to educate youth all over India on climate change. Finally, MigrantWatch, an organization dedicated to watching bird migrations across India, has since 2007 reported that the focus of it work is 'to track bird migration in relation to climate change' (MigrantWatch 2013).

We term the process described above 'crowding-in', defined as the rapid increase in the number and diversity of organizations operating in a given issue 
field $^{2}$. We will argue that a key contributor to such crowding-in processes are the activities of international institutions. We do however recognize that the relationship between these institutions and CSOs is not unidirectional. Since the late nineteenth century, international environmental CSOs have been instrumental in the long process leading to the development of the world environmental regime (Meyer et al. 1997a), the formation of UNEP in 1972 (Hironaka 2014), the founding of UNFCCC in 1992 (Newell 2000) and the subsequent rise of climate change on the global political agenda. National CSOs do also impact on national and even global political agendas, as the abovementioned cases of CSE and TERI illustrate. The shorter-term process of crowding-in, the focus of this paper, however, takes place in a context where the issue of climate change is already on the global agenda, and at this point, it appears that the activities of national-level CSOs are significantly more driven by global developments than the other way around. The following five sections introduce five mechanisms that we argue are the driving force of the crowding-in process, and present evidence from our interviews and document sources to support this argument.

\section{Expansion of discursive opportunities}

The social movement literature on discursive opportunities suggests that the heightened visibility of an issue in the mass media increases the mobilization of social movement organizations around that issue (Koopmans and Statham 1999; Koopmans and Olzak 2004). We argue that discursive opportunities should be understood in a broader sense, to include not only the media, but also long-term changes in global institutional structures and the discourses promoted by these 
institutions, as well as civil society organizations themselves (for examples of a comparable broad approach to discursive opportunities, see Ferree et al. 2002; Wahlström and Peterson 2006).

As figure 1 shows, media attention to climate change in India, indeed, increased sharply, and this increase broadly coincides with the period during which the crowding-in process took place. The two key events most frequently mentioned by our interviewees that contributed to this increase are the publication of the fourth assessment report by the IPCC in 2007 and the Copenhagen COP in 2009. This suggests that behind the short-term media agenda is a longer term process of institutionalization of global climate science in the IPCC and global climate politics in the UN COPs, both of which had at this point reached a state where they became major news.

For some CSOs, the expansion of discursive opportunities has provided opportunities for what Snow et al. (1986) call frame extension. In politics of climate change, Jinnah has called this phenomenon climate change bandwagoning, involving "discursively re-framing issues in a way that foregrounds the climate benefits of the original/source issue" (Jinnah, 2011: 3). This occurs when organizations extend their current core frames to relate them to climate change. The small farmers' organization La Via Campesina South Asia, for example, now connects its core frame 'food sovereignty' to climate change. ${ }^{3}$

For us, the climate crisis is actually an opportunity to promote food sovereignty. Food sovereignty is the solution to climate change from the agricultural point of view. It's also a way for us to oppose industrial 
agriculture that causes climate change. It all plays into the debate on food sovereignty and global warming... there's a new angle to it. (INT3)

It must be noted, however, that the number of new CSOs entering the issue field began to rise earlier than the number of newspaper articles on climate change. Thus, it is not that CSOs jumped on a bandwagon of media hype.

When asked when and why they began working on climate change, most interviewees told a story about somehow realizing around 2007 or 2008 that what they were doing previously was somehow connected to the issue of climate change. Thus, in 2008, the youth organization Delhi Greens started to 'raise the issue of irrational and unmindful felling of trees in Delhi'; 'immediately after, we realized that climate change was also part of urban sustainability' and went on to launch the Delhi Youth Summit on Climate' (INT16).

Some organizations strongly deny that the increased salience of the climate issue had motivated them:

We are a group focusing on a variety of social issues, and climate justice is a critical part of any action or initiative. So we did not join this as a fad... we don't want to coin this climate justice as a term just because some academics and the US started talking about it. (INT18)

The fact that CSOs' entry into the field peaked before the corresponding media attention and the self-understanding of the organizations suggests that domestic mass media attention was not the main mechanism driving the crowding-in 
process. Media coverage in Europe and North America, however, was already high in 2007-8 (Daly et al. 2015), so it is possible that CSOs take cues from globally influential mass media outlets, such as the Guardian and the New York Times. Other likely sources of information are key organizations in global civil society networks and related communication channels, such as websites and social media, all of which directly follow the activities of global scientific and political institutions. Moreover, the mechanism linking media attention and CSO activity is likely to work in both directions: organizational activities aimed at influencing public opinion contribute to the increase in coverage, which, in turn, attracts more CSOs to the field. In this sense, CSOs partly create their own discursive opportunities.

\section{Event effects}

World society scholars have shown that conferences in international institutions have been an important catalyst in the increase in number of international CSOs. While the statistical evidence remains inconclusive across all issue fields, in the field of environmentalism research as shown that UN summits, beginning with the Stockholm Conference in 1972, continuing with the Earth Summit in 1992 and beyond have coincided with an increase in the number of international environmental CSOs (Sikkink and Smith 2002; Khagam 2002). Furthermore, there is case study evidence suggesting that, for instance, the 1975 Helsinki Conference on Human Rights was important in mobilizing international human rights CSOs (Thomas 2002), the UN's 1993 Beijing Conference on Women was important for the international women's movement (True and Mintrom 2001), and the mobilizations around the 1999 WTO conference in Seattle and 
subsequent conferences of the G8, IMF and World Bank were a defining feature of the global justice movement (Author A). In this section, we argue that this mechanism observed in research on international CSOs we call the event effect also operates to mobilize CSOs at the national level around global issues, such as climate change.

The annual UN climate conferences, or COPs, are frequently mentioned by our interviewees as focal points of their activities. One of these, the COP 15 in Copenhagen in 2009 is mentioned by almost all as an important milestone. The peak year of new organizations entering the field, however, is not 2009, but the two years preceding it. More than the single event of the COP 15, then, it was the string of annual COPs that drew organizations to the field. But as the UNFCCC and the press frequently framed the 2007 and 2008 COPs as meetings preparing for the big one in 2009, where the treaty to replace the Kyoto Protocol was to be signed, COP 15 grew to be an extremely important symbolic rallying point that everyone still talks about.

This urgency is particularly great in light of the upcoming Copenhagen climate negotiations in December, where an ambitious, equitable, and effective successor to the Kyoto Protocol needs to be established. (Da Costa 2009)

Others recall, 'When we were going to Copenhagen, that time Jairam Ramesh was there and there was this whole gaze, all the [TV] channels were there' (INT12), and 'when Copenhagen was going on, we did activities also in South 
India and Bangladesh' (INT4). One coalition established in the run-up to COP 15 was named the Beyond Copenhagen Coalition to reflect the importance of the event and to point out that one should not be overly hopeful about a single meeting. Many organizations clearly see their climate change work in pre- and post-Copenhagen phases:

This was pre-Copenhagen, and this was largely for India to also take a proactive position in Copenhagen... And after Copenhagen, of course, our campaigns became largely nationally oriented, looking at the energy sector. (INT20)

Thus, while Copenhagen was an important rallying point, the failure to achieve a binding international treaty also influenced how CSOs conceptualize their present work on climate change.

Second, COPs in general, and the Copenhagen COP 15 in particular, have generated opportunities for concrete CSO participation in the global political process. For the major players like the CSE and TERI, this is evidently so as they have regularly participated and closely collaborated with the Indian government delegation. However, during the process of intense mobilization from 2007 to 2009, many delegates from much smaller organizations, some of which had just entered the field of climate change and others of which were established just for that purpose, participated in COPs and their side events. Many journalists also seized the opportunity created by COP 15 . Their participation was closely tied to civil society mobilization as the CSE sponsored the attendance of many 
journalists and held regular briefings for them on the progress of the negotiations (INT12).

\section{Network effects}

A key finding in the literature on social movement networks is that existing organizational structures and inter-organizational and personal networks facilitate mobilization (Diani and McAdam 2003). These organizations and network connections between them that have been formed earlier for another (often but not always related) purpose are reactivated and to some extent restructured to facilitate mobilization on a new issue.

What is more, these networks are embedded in organizational fields (Curtis and Zurcher 1973; Di Maggio and Powell 1983), characterized by shared understandings and models of organization and action. These cultural factors, in addition to already existing network ties, are what enables network expansion, that is, crowding-in.

To a certain extent our case looks like a standard world society story, where international NGOs bring in an emerging global issue and a models to act on in (Longhofer and Schofer 2010; Frank et al. 2007). However, this perspective alone cannot explain the extent to which crowding-in on the issue of climate change has taken place. Inter-organizational networks built during earlier social movement mobilizations and reactivated as climate change networks, as well as personal networks that extend across organizations that were also key drivers of the crowding-in process. These kinds of networks are not captured by the quantitative datasets used by most world society analysts, but are, nevertheless, an important contributor to the processes that world society scholars are 
interested in. All of the networks we present below, from the most institutionalized to the most informal include important transnational connections.

To start with the part of the story that most obviously ties in with the world society perspective, the most visible network is Climate Action Network South Asia, the regional branch of the world's largest and best-known CSO network CAN. Its membership includes the obvious international environmental NGOs such as the WWF and Greenpeace, but has also expanded to development organizations such as Oxfam and Action Aid.

The existence of CANSA as an institution facilitates further crowding-in. New organizations wishing to do work on climate change can join an existing network, that offers the new entrants not only a model for organizing but to possibility to access resources such as political access and funding. CANSA provides Indian organizations with a degree of access to the global negotiating tables through its relatively established role vis-à-vis the UNFCCC. It is also a structure for North-South flows of funds for CSO work on climate change: CANSA is funded by large international NGOs (such as Oxfam and Christian Aid), as well as intergovernmental institutions like the European Commission.

The birth and expansion of another major CSO climate change network, Climate Justice Now!, is an example of how network connections originally forged for another purpose can facilitate a crowding-in process on a new issue. CJN! was built on networks created by the Global Justice Movement in the late 1990 's and early 2000's. By 2007 that cycle of protest had mostly waned, following, among other things, the waning of a key target of the movement, the 
interstate negotiations at the World Trade Organization. During the UN COP 13 in Bali in 2007, many global justice organizations followed the international agenda, moving to the issue field of climate change and establishing CJN! (Reitan and Gibson 2012; Hadden 2015). CJN! lists 730 member organizations, of which 29 are in India (CJN! 2014). This building of new networks on the old considerably increased the diversity of organizations involved in climate change advocacy, with organizations such as the Borok Peoples' Human Rights Organization and Kerala Coconut Farmers Association, joining the CJN!.

Most member organizations of CJN! are not registered as environmental organizations in any database, nor is the network itself institutionalized enough to appear in the radar of most world society analysis. Despite its ephemeral nature, Fisher (2010) and Hadden (2015) estimate that it has had significant effects on the global climate negotiations, and it did contribute significantly to the process of crowding-in in India.

Another network type that is even less visible, pre-existing interpersonal networks, are also activated to further boost the process of crowding-in during periods of high mobilization. While it is hardly unpredictable that organizations like WWF or Greenpeace take on the issue of climate change, the case of a chairperson of a student cultural organization at one of India's most reputed universities is somewhat more surprising. He explains:

I was at a book fair and met the cultural secretary of the American Information Center. I knew her; she had attended various cultural programmes at my campus. So, all of a sudden, she asks me: 'you're always 
involved in organizing cultural events, why don't you organize something related to global warming?'... and then, because of this successful programme, the Al Gore organization approached me and told me that Al Gore is going to train people in Melbourne and asked whether I could join this training session. (INT06)

He went on to found a student organization on climate change advocacy. Informal international networks also play a role in channelling funding to organizations entering the expanding field of climate change politics. Another example involves an organization in need of the equivalent of 500 Euros to fund the travels of local grassroots organizations to consultations on the effects of climate change. A telephone call to an acquaintance at the Indian chapter of a major international development CSO sufficed to secure the funds, which allowed for the participation of several grassroots organizations, not previously active on the issue, in the politics of climate change.

These examples demonstrate that below the formal networks and large-scale flows of funds from major donor agencies on which fairly reliable quantitative data exists, there is another layer of networks adding momentum to crowding-in processes. Our findings about the reactivated social movement networks and interpersonal networks, of course, do not call into question the basic world society idea that the origins of the crowding-in process lie in global institutions. What they do show is that once the process is in motion, there are network effects beyond those usually discussed in the world society literature that boost 
national-level mobilization on a global issue to create the intense burst of activity we call crowding-in.

\section{Repertoire adoption and innovation}

Early on, CSO work on climate change consisted mostly of expert tasks like writing research reports and lobbying policymakers. During the crowding-in process, the climate change movement expanded its action repertoire, which made it possible for new organizations to become involved - even those that did not have the capability or desire to carry out expert work. A division of labour emerged within the movement, whereby the early entrants to the field mainly continued their expert work while many of the newcomer organizations took on social movement type activities. Events based on mass participation and campaigns to raise awareness of the general public on climate change, as well as actions aimed at collecting first-hand testimonies from ordinary people whose lives are adversely affected by climate change became part of the movement's repertoire.

To take an example, La Via Campesina South Asia, a farmer's organization that was a newcomer to climate change politics, organized a colourful climate caravan through Bangladesh, where they were joined by activists from several countries, to educate local communities about the effects of climate change on their livelihoods (La Via Campesina 2011). Similarly - but in a very different urban setting and rhetorical style - the Indian Youth Climate Network organized the Climate Solutions Road Tour, travelling across 15 cities to organize 'leadership trainings' on climate change in colleges and schools. They were accompanied by a solar-powered electric band called Solar Punch and travelled 
in a medley of alternatively-powered vehicles, including electric cars sponsored by their manufacturer, Reva, a solar panel roofed jeep and a van running on waste vegetable oil (INT11; Da Costa 2009). Both caravans were initiatives of organizations that could not have been part of the climate change movement, had its repertoire not expanded beyond the initial focus on expert inside tactics.

Another element that was introduced in the movement's action repertoire in 2009 , in the run-up to the Copenhagen COP, was climate justice tribunals. The idea is to bring people whose lives are adversely affected by climate change to testify before a jury, which then gives its verdict and proposes possible ways to use existing international law to demand compensation from polluters. This action form dates back to peace movement and the 1966 Russell Tribunal organized by the philosopher and activist Bertrand Russell for war crimes in Vietnam. Subsequent tribunals have examined, among other cases, the Soviet intervention in Afghanistan, the Armenian genocide and Japanese military sexual slavery (Chinkin 2001: 338-9).

At the National People's Tribunal on the Climate Crisis held in Delhi 16 November 2010,

'Animesh Giri from West Bengal said: "Local ecology has been affected so much that indigenous fruits and products which were the main source of their food have completely vanished", and Ms. Ajantha, representing fisherwomen from Negapattinam, Tamilnadu, said that their lives have gone completely out of gear due to changes in the weather cycle and frequent extreme climatic events' (Beyond Copenhagen Coalition 2010). 
Again, this action form brought in new organizations previously not active in the field of climate change. These organizations focussing on issues like rural poverty and agriculture teamed up with the international development NGO Oxfam to organize a series of tribunals, culminating in testimonies in a highprofile event at the Copenhagen COP, but continuing also beyond that meeting. This action form introduces "the logic of bearing witness to injustice" (Della Porta and Diani 2006: 171), typical of the social movement repertoire, alongside an expert logic that dominated earlier and thus, broadens the possibilities of participation. Repertoire adoption combined with event effects of the COP15 and network effects involving links between international CSOs and Indian organizations to contribute to the crowding-in process.

\section{The global pressure effect}

By the global pressure effect we refer to a mechanism by which activities of global institutions open up the political opportunity structure to CSOs at the state and local levels. This effect increases the number and diversity of CSOs working on climate change by offering opportunities especially to small and locally oriented CSOs to get involved in climate change politics.

There is huge pressure in international negotiations for reduction commitments from major economies like India, South Africa, China, Brazil. And India also wants to be seen as doing something about its own contribution to climate stabilization. International pressure works fantastically; in India, many of the important legislations or plans have resulted from international pressure. (INT5) 
Like many of our interviewees, academic observers have argued that pressure from global climate change negotiations has influenced India's national climate policymaking (Dubash 2009; Vihma 2011). Despite India's hard-line negotiating stance, refusing to take on binding commitments, the federal government has drafted a National Action Plan on Climate Change, which has been translated into state-level action plans for implementation by state governments.

From a civil society perspective, these developments offer new opportunities for action, particularly from smaller and less resourceful organizations. Such organizations may not have the resources to travel to UN meetings to influence the global policymaking process, or connections to federal policy elites in Delhi, but they may be fairly well connected at the state and local levels.

In 2011, a series of consultations on the state-level action plans was organized, bringing together small local CSOs, state government ministers, officials and academics. The network effects of global and local interpersonal networks interacted with global pressure effects to make the consultations possible. Global network connections secured the funding for the first consultations from Oxfam. Local personal networks then secured access to policymakers and state funding for subsequent consultations. The state of Bihar agreed to fund the consultations 'because we knew one of the ministers; we had had previous interaction with the government'. In Karnataka, 'I met this very senior government officer and brought this up, so he immediately phoned the government department', a call that eventually led to the twenty district-level consultations being organized and funded by the government. In Nagaland, the government first refused to give its draft of the state-level plan to the CSOs for 
comment, but then, 'they gave it to this one [CSO] group because one minister was some relative of one of their leaders' (INT1).

That international institutions affect states is the basic argument of the sociology of world society (Meyer et al. 1997b). That they also affect civil societies has also been well established (Longhofer and Schofer 2010). We argue that there is also a more complicated relationship between these three, whereby global institutions push states to act, which then opens new opportunities for CSOs at the national and local levels. This mechanism contributes to crowding-in by enabling entry to the field to organizations that do not have the financial resources or personal networks that enable them to act on a global scale, but can leverage local organizational resources and connections.

\section{Discussion and conclusions}

We have argued that despite the widespread skepticism about the effectiveness of global institutions in general and the climate regime in particular, these institutions are having very tangible effects not only on states, but also on civil societies around the world. While most world society studies have used quantitative macro data to establish that such a causal relationship exists, in this paper we have undertaken a single country case study to examine in detail the mechanisms through which the interaction between global institutions and nationally and locally rooted civil societies happens.

Our first contribution to the world society literature has been to argue that the influence of world society on national political processes often occurs not in a linear fashion but in intense bursts of activity - captured by our concept of crowding-in. Our second contribution has been to show how five mechanisms, 
each with a strong link to global institutions, have contributed to crowding-in of CSOs to the field of climate change at the national level in India. These are (1) the expansion of discursive opportunities generated by global scientific and political institutions, (2) the event effects of the international climate change conferences, (3) the network effects of globally connected CSO networks, (4) the adoption of elements of the globally diffused cultural repertoire of action and (5) the global pressure effect that has spurred the Indian state to act, creating new opportunities for national and local CSOs. Figure II sums up our argument.

\section{Figure II. The five mechanisms of crowding-in.}

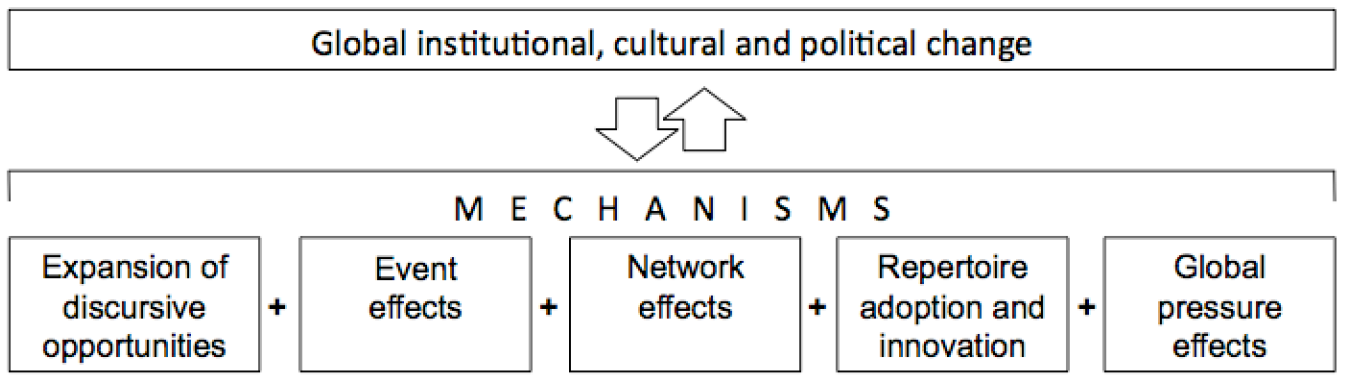

Our analysis of the crowding-in process in the wider context - a world society perspective - also allows us to contribute to the social movements literature. Our argument here has been that accounts focusing on the internal workings of national mobilization processes without placing them in the global context run the risk of exaggerating the autonomous character of such mobilizations.

To what extent are our conclusions transferable beyond the case of climate change politics in India? Does crowding-in occur in other countries and other policy fields, and are the mechanisms same everywhere? First, crowding-in on 
climate change seems to take place beyond India. Cabré (2011) and Hadden (2015) have documented an increase in the number and diversity of CSOs participating in the UN COPs from all countries. In the light of these findings, it is reasonable to hypothesize that a national level process of crowding-in to this issue field has occurred in many other countries besides India. We do, however, have several reasons to presume that this process has been stronger in India than in most other countries. As explained in the introduction to justify our case selection, these include the facts that the effects of climate change in India are stronger than elsewhere, that Indian civil society is stronger than most, and that world society influence on civil societies has tended to be stronger in countries of the Global South.

Second, crowding-in of CSOs has occurred on issue fields other than climate change, and global institutions have been an important driver of these processes. HIV/AIDS organizations in Africa are the most conspicuous example (Hershey, 2013).

Third, our explanatory strategy has focussed on mechanisms whose presence in several mobilization processes across countries and issue fields has been extensively documented in the social movement literature. Therefore, we would expect these mechanisms to be present, at least so some degree, in crowding-in processes in other countries and on other issue fields as well. The exact extent to which the mechanisms and their interactions are the same across cases is something that future comparative research needs to address. 


\section{Appendix I. Interviews}

Organization

INT1 Bharat Jan Vigyan Jatha

INT2 Tehelka Magazine

INT3 La Via Campesina South Asia

INT4 South Asian Dialogues on Ecological Democracy (SADED)

INT5 Public Advocacy Initiatives for Rights and Values in India

INT6 Prakriti Ke Sipahi

INT7 Carbon Minus India

INT8 Development Alternatives

INT9 Centre for Science and Environment

INT10 The Energy and Resources Institute

INT11 Indian Youth Climate Network

INT12 Headline Today (ex)

INT13 TERI Magazine Terra Green

INT14 Toxic Links/Learn Today (ex)

INT15 Climate Action Network South Asia/World Wildlife Fund

INT16 Delhi Greens

INT17 Center for Social Markets

INT18 Environment Support Group

INT19 Khoj International Artists' Association

INT20 Greenpeace

INT21 Indian Network on Ethics and Climate Change

\section{Date}

14 January 2012

16 January 2012

16 January 2012

18 January 2012

19 January 2012

9 January 2013

9 January 2013

10 January 2013

10 January 2013

11 January 2013

22 February 2013

27 February 2013

12 March 2013

20 March 2013

22 March 2013

22 March 2013

16 April 2013

16 April 2013

17 April 2013

18 April 2013

7 April 2015 


\section{Notes}

1. Acknowledgment omitted from the manuscript to fully anonymize the text for review.

2. In economics, the concept of 'crowding in' is used to describe the idea that deficit spending by governments during economic downturns boosts demand and crowds in private enterprise, increases private investment and boosts economic growth (Friedman 1979). Our loosely parallel definition is inspired by this idea, but intended for investigating political processes more generally.

3. Food sovereignty is a concept coined by La Via Campesina as its main activity frame. It is 'the right of the people who produce, distribute, and consume food to control the mechanisms and policies of food production' (see Author A, 2011).

\section{Bibliography}

Agarwal, A. and Narain, S. 1991 Global Warming in an Unequal World: A Case of Environmental Colonialism, New Delhi: CSE.

Beyond Copenhagen Coalition 2010 'The National People's Tribunal on the Climate Crisis', press release, available at http://www.oxfamindia.org/sites/default/files/NATIONAL\%20PEOPLES\%20TR IBUNAL\%200N\%20CLIMATE\%20CRISIS.pdf.

Bosi, L. Demetriou, C. and Malthaner, S. 2014 'A Contentious Politics Approach to the Explanation of Rationalization', in L. Bosi, C. Demetriou and S. Malthaner (eds) Dynamics of Political Violence, Burlington: Ashgate, 1-26. 
Boyle, E.H. 2002. Female Genital Cutting. Cultural Conflict in the Global Community. Baltimore: Johns Hopkins UP.

Cabré, M.M. 2011 'Issue-linkages to Climate Change Measured through NGO Participation in the UNFCCC', Global Environmental Politics 11(3): 10-22.

Chinkin, C.M. 2001 ‘Women’s International Tribunal on Japanese Military Sexual Slavery', The American Journal of International Law 95(2): 335-341.

CJN 2014 CJN! Network Members, available at http://www.climate-justicenow.org/category/climate-justice-movement/cjn-members/.

Curtis, R. L. and Zurcher, L. A. 1973 'Stable resources of protest movements: the multi-organizational field.' Social forces, 52(1): 53-61.

Da Costa, A. 2009 Climate Road Trip: An Indian Movement for Change, available at http://www.worldwatch.org/node/5977.

Daly, M., Gifford, L., Luedecke, G., McAllister, L., Nacu-Schmidt, A., Wang, X., Andrews, K. and Boykoff, M. 2015 World Newspaper Coverage of Climate Change or Global Warming, 2000-2015, available at http://sciencepolicy.colorado.edu/media coverage.

della Porta, D. 2014 'In-Depth Interviews' In della Porta, D. (ed.) Methodological Practices in Social Movement Research. Oxford: Oxford University Press.

della Porta, D., and Diani, M. 2006 Social Movements: An Introduction. Oxford: Blackwell.

Dharmadhikary, S. et al. 2009 'NAPCC and the National Water Mission. A Letter from Civil Society Organizations to the Prime Minister of India'. 
Diani, M. and McAdam, D. 2003 Social Movements and Networks. Relational Approaches to Collective Action, Oxford: Oxford University Press.

DiMaggio, P. and Powell, W. 1983 'The iron cage revisited: institutional isomorphism and collective rationality in organizational fields'. American Sociological Review 48(2): 147-60.

Dubash, N. 2009 'Toward a Progressive Indian and Global Climate Politics', CPR Working Paper 2009/1, New Delhi: CPR.

Ferree, M.M et al. 2002 Shaping Abortion Discourse: Democracy and the Public Sphere in Germany and the United States. New York: Cambridge UP.

Fisher, D. 2010 'COP-15 in Copenhagen: How the Merging of Movements Left Civil Society Out In the Cold.' Global Environmental Politics 10(2): 11-17.

Frank, D., Hironaka A. and Schofer E. 2000 'The Nation State and the Natural Environment over the Twentieth Century'. American Sociological Review, 65:1 96-116.

Frank, D., Longhofer, W. and Schofer, E. 2007 'World Society, NGOs and Environmental Policy Reform in Asia'. International Journal of Comparative Sociology 48(4-5): 275-295.

Friedman, B. 1979 'Crowding out or Crowding in? The Economic Consequences of Financing Government Deficits', NBER Working Paper No. 284. George, A.L. and Bennett, A. 2005 Case Studies and Theory Development in the Social Sciences, MIT Press.

Haas, P.M. 1992 'Introduction: Epistemic Communities and International Policy Coordination', International Organization 46(01): 1-35. 
Hadden, J. 2015 Networks in Contention. The Divisive Politics of Climate Change. Cambridge: Cambridge UP.

Hershey, M. 2013 'Explaining the non-governmental organization (NGO) boom: the case of HIV/AIDS NGOs in Kenya'. Journal of Eastern African Studies $7(4): 671-690$.

Hironaka, A. 2014 Greening the Globe. World Society and Environmental Change. New York: Cambridge UP

Jinnah, S. 2011 'Climate Change Bandwagoning: The Impacts of Strategic Linkages on Regime Design, Maintenance, and Death. Global Environmental Politics 11(3): 1-9.

Khagram, S. 2002 'Restructuring the Global Politics of Development: The Case of India's Narmada Valley Dams', in S. Khagram, J.V. Riker and K. Sikkink (eds) Restructuring World Politics: Transnational Social Movements, Networks, and Norms, Minneapolis: University of Minnesota Press, 206-230.

Koopmans, R. and Statham, P. 1999 ‘Ethnic and Civic Conceptions of Nationhood and the Differential Success of the Extreme Right in Germany and Italy', in M. Giugni, D. McAdam and C. Tilly (eds) How Social Movements Matter, Minneapolis: University of Minnesota Press, 225-251.

Koopmans, R. and Olzak, S. 2004 'Discursive Opportunities and the Evolution of Right-Wing Violence in Germany', American Journal of Sociology 110(1): 198-230.

Krause, M. 2014 The Good Project: Humanitarian Relief NGOs and the Fragmentation of Reason. Chicago: University of Chicago Press.

Kvale, S. 2008 Doing interviews. London: Sage. 
La Via Campesina 2011 'Declaration of the South Asian Caravan on Climate, Gender, and Food Sovereignty', available at http://lvcsouthasia.blogspot.fi/2011/12/south-asia-climate-caravan-in.html.

Lele, S. 2012 'Climate Change and the Indian Environmental Movement', in N. Dubash (ed.) Handbook of Climate Change and India: Development, Politics and Governance, Delhi: Oxford University Press.

Longhofer, W. and Schofer, E. 2010 'National and Global Origins of Environmental Association', American Sociological Review 75(4): 505-533.

McAdam, D., Tarrow, S. and Tilly, C. 2001 Dynamics of Contention, Cambridge: Cambridge University Press.

McAdam, D., Tarrow, S. and Tilly, C. 2008 'Methods for Measuring Mechanisms of Contention', Qualitative Sociology 31(4): 307-331.

McCracken, G. D. 1998 The Long Interview. London: Sage.

McGann, J.G. 2013 '2013 Global Go to Think Tank Index Report', available at http://gotothinktank.com/dev1/wpcontent/uploads/2014/01/GoToReport2013.pdf.

Mehra, M. 2010 Who's Who in Climate Change in India, Bangalore: Centre for Social Markets.

Meyer, J.W. et al. 1997a 'The Structuring of a World Environmental Regime, 1870-1990', International Organization 51(04): 623-651.

Meyer, J.W. et al. 1997b World Society and the Nation-State. American Journal of Sociology 103(1): 144-181.

Miller, R. L. 2000 Researching Life Stories and Family Histories. London: Sage. 
MigrantWatch 2013 'Welcome to MigrantWatch' available at http://www.migrantwatch.in/.

Newell, P. 2000 Climate for Change: Non-State Actors and the Global Politics of the Greenhouse, Cambridge: Cambridge University Press.

Rahman, A. and Ronceler, A. 1994 'A View from the Ground Up', in M. Mintzer and J.A. Leonard (eds) Negotiating Climate Change, Cambridge: Cambridge University Press: 239-277.

Reitan, R. and Gibson, S. 2012 'Climate Change or Social Change? Environmental and Leftist Praxis and Participatory Action Research', Globalizations 9(3): 395-410.

Schofer, E. and Hironaka, A. 2005 'The Effects of World Society on Environmental Protection Outcomes', Social Forces 84(1): 25-47.

Sikkink, K. and Smith, J. 2002 'Infrastructures for Change: Transnational Organizations, 1953-1993', in S. Khagram, J.V. Riker and K. Sikkink (eds) Restructuring World Politics: Transnational Social Movements, Networks, and Norms, Minneapolis: University of Minnesota Press.

Snow, D. A., Rochford E. B., Worden, S. K., and Benford, R. D. 1986 'Frame Alignment Processes, Micromobilization, and Movement Participation'. American Sociological Review, 51: 464-481.

Thomas D.C. 2002 'Human Rights in US Foreign Policy', in S. Khagram, J.V. Riker and K. Sikkink (eds) Restructuring World Politics: Transnational Social Movements, Networks, and Norms, Minneapolis: University of Minnesota Press. Tilly, C. 2001 'Mechanisms in Political Processes', Annual Review of Political Science 4(1): 21-41. 
True, J. and Mintrom, M. 2001 'Transnational Networks and Policy Diffusion: The Case of Gender Mainstreaming', International Studies Quarterly 45(1): 2757.

Tsutsui, K. 2006 'Redressing Past Human Rights Violations: Global Dimensions of Contemporary Social Movements', Social Forces 85(1): 331-354.

Tsutsui, K. and Shin, H.J. 2008 'Global Norms, Local Activism, and Social Movement Outcomes: Global Human Rights and Resident Koreans in Japan', Social Problems 55(3): 391-418.

Vihma, A. 2011 'India and the Global Climate Governance: Between Principles and Pragmatism', Journal of Environment \& Development 20(1): 69-82.

Wahlström, M. and Peterson, A. 2006 'Between the State and the Market Expanding the Concept of "Political Opportunity Structure"', Acta Sociologica 49(4): 363-377.

Weiss, R. S. 1994 Learning from Strangers. The Art and Method of Qualitative Interview Studies. New York: The Free Press. 